\title{
Synthesis and Properties of Soaps from Bidara leaf (Ziziphus mauritania) Via Soft Saponification
}

\author{
MARIA ULFA ${ }^{1}$ and DENIS EKA CAHYANI ${ }^{2}$ \\ ${ }^{1}$ Chemical Education Study Program, Faculty of Teacher Training and Education, Sebelas Maret University, \\ JI. Ir. Sutami 36A, Surakarta 57126, Central Java Indonesia. \\ ${ }^{2}$ Department of Chemistry, Faculty of Mathematics and Natural Sciences, Sebelas Maret University, \\ JI. Ir. Sutami 36A, Surakarta 57126, Central Java Indonesia. \\ *Corresponding author E-mail: ulfa.maria2015@gmail.com \\ http://dx.doi.org/10.13005/ojc/350254
}

(Received: September 23, 2018; Accepted: March 13, 2019)

\begin{abstract}
This article was aimed to compare soap character with the difference concentration of bidara leaf extraction. Bidara leaf soap was prepared by soft saponification using $\mathrm{NaOH}$ which is involved with bidara leaf. Soap analysis has been investigated by colour, cleaning power, foam power dan $\mathrm{pH}$. Based on the result, the soap with $2 \%$ concentration of bidara leaf had the highest cleaning power with soft texture, high soap power and appropriate $\mathrm{pH}$ for skin care. From FTIR observation and manual soap test was predicted that bidara leaf not only act as catalyst that increase saponification rate but also act as soap hidrophilicity enhancer.
\end{abstract}

Keywords: Bidara leaf (ziziphus Mauritania), Saponification, Cleaning power, Texture, pH.

\section{INTRODUCTION}

Soaps that have been known for centuries are the main human needs in maintaining body cleanliness. Today, soap is not only synthesized from conventional substances, namely sodium or potassium bases with fatty acids, but has evolved by activating many other natural ingredients. The fatty acids used in making soap are animal fats, coconut, palm oil and olive oil (Pohl et al., 2012). Good quality like a lot of foaming, high power, not hard, smooth and soft is not only detective by fatty acids but also by certain plant extracts (Phanstiel et al., 1998). Modern soap making innovations have used the manufacture of ordinary soap which is not only soap as a cleaning material but also medicine for medicine (Mabrouk, 2005).

Many are used here that can improve quality by using extraction of plants such as avocados, green tea (Katz, 2000; Robertson, 2009). The results obtained are global natural green color soaps with various sizes that not only cleanse the skin. Soap research is very efficient and is done a lot but is still a lot done with soap that hasn't been done much.

This is an Open Access article licensed under a Creative Commons license: Attribution 4.0 International (CC- BY). Published by Oriental Scientific Publishing Company @ 2018 
Bidara leaves (Ziziphus mauritiana) are tropical plants which are also known as chine apple, jujube and indian jujube. This plant produces leaves and fruit that can cause many diseases such as liver disorders, stomach problems, diarrhea, sedatives, tonics, anticancer, nausea and fever. The pharmacognostic and pharmacological activity of the Bidara Leaf (Ziziphus mauritiana) effectively reduces rheumatism, asthma and gum inflammation. Surabaya leaf research (Ziziphus mauritiana) has very high antimicrobial activity extracted with ethanol and contacted with various species such as Escherichia coli, Staphylococcus aureus, Streptococcus pyogenes, Aspergillus niger and Candida albicans. In addition, several studies have suggested that bidara leaves have a very high regenerative effect. This value is rarely used when making soap. The traditional use of leaves is rarely done by studying physicochemical physical properties. This has caused the supply in soap to not be tested for exact quality.

In this study we will focus on making bidara leaf soap. Our bidara extraction is done by ethanol maceration. Then followed by a saponification process involving bidara leaf extract until the freezing and printing process. The variation of the concentration of bidara leaf extract in soap making was done to investigate the effect of bidara leaf extract on the quality of soap. The nature of the functional groups of bidara leaf extract and bidara leaf soap we examined through FTIR spectra observation. Other soap properties such as $\mathrm{pH}$, clean power, hardness and color are tested by manual testing.

\section{EXPERIMENTAL}

\section{Material}

Palm oil, olive oil and sunflower oil are obtained from nearby stores around Solo. Chemicals include sodium hydroxide, glycerin, deionized and fragrance water obtained from Sigma with analytical grade quality. Bidara leaves were obtained from the Darpes Fath Boyolali plantation.

\section{Bidara leaves extraction}

Bidara leaves are cleaned and then smoothed. Then the bidara leaf powder was macerated at room temperature for $24 \mathrm{~h}$ using in a ratio of $1: 10(b / b)$. Bidara leaf porridge is then filtered with Whatman paper. The filtrate is then evaporated with a vacuator evacuator for 8 hours. Extraction results are stored in the freezer for further use.

\section{Preparation of Soap from Bidara leaves}

Palm oil, olive oil and oil Sunflower is heated to $7^{\circ} \mathrm{C}$ for $30 \mathrm{~min}$ then mixed into a $30 \%$ $\mathrm{NaOH}$ solution with a ratio of $1: 1(\mathrm{v} / \mathrm{v})$. The mixture continues to stir until thickened and then added $1 \%$ bidara leaf extract while stirring for 2 hours. Other ingredients are added to the mixture and then followed by the printing process. The mold is covered in plastic wrap and then cooled to room temperature for 3-4 days. Soap with other variations is made with $2 \%$ and $3 \%$ bidara concentrations. The soap obtained was named SB- $x \%$ with $x$ being the added concentration of the bidara extract.

\section{Characterization}

The functional group content was observed with FTIR spectroscopy (Shimadzu 3200) at a wavelength of $400-4000 \mathrm{~cm}^{-1}$. Morphology with FTIR and SEM-EDAX. Physical performance is done by observing color, texture, foam and cleaning power. Determination of $\mathrm{pH}$ was determined using a $\mathrm{pH}$ meter ( $827 \mathrm{pH}$ model lab). $1 \mathrm{~g}$ of soap is weighed and dissolved in distilled water in a $100 \mathrm{ml}$ volumetric flask. The $\mathrm{pH}$ meter electrode is inserted into the solution and the $\mathrm{pH}$ is recorded. Foam power is measured by shaking $2 \%$ soap solution until foaming and the height of the foam is measured by the ruler. Foam power is calculated in \% by comparing foam height immediately after shaking with foam height after $5 \mathrm{~min}$ of silencing (unit\%). Foam height in solution is measured and recorded. Clean power is measured by placing a drop of fried oil on paper Then filter paper. soaked in $2 \%$ soap solution while shaking 1 minute. Difference in diameter of oil before and after shaking is measured and calculated the percentage of net power in $\%$.

\section{RESULT AND DISCUSSION}

Figure 1 is a sequel to soap products that were successfully recorded during the soap making process. Fig. 1. a is a bidara leaf powder that is ready to macerate with ethanol into a bidara leaf solution (Fig. 1.b). Looks powder is still clumping because it still has a fairly high water content. The extraction and saponfication process with printing and ripening for 2-4 days in Fig. $1 \mathrm{c}$ shows a yellowish 
soap slurry. At the time of harvest, SB-1\% soap appears to have been successfully made with the characteristic whitish cream. Soap color analysis will be discussed further on the results of manual tests. Then to find out the effect of bidara leaves on soap, the morphological observation of bidara leaf extract will be started microscopically using SEM in Figure. 2.

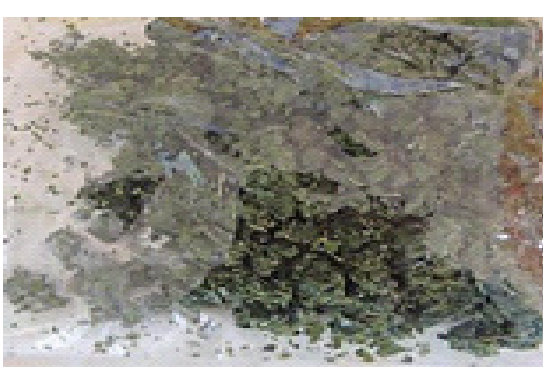

(a)

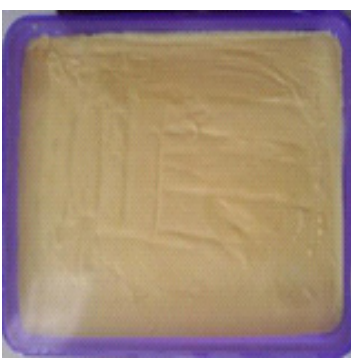

(c)

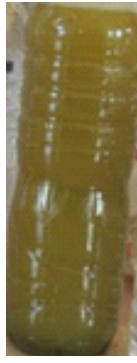

(b)

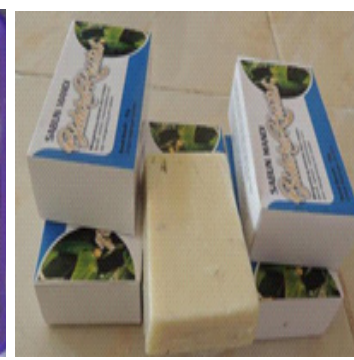

(d)
Fig. 1. Results of images with conventional cameras on a. bidara leaf powder, b. bidara leaf solution in ethanol, c. results of printing soap, d. ready to use soap

Figure 2 is the result of SEM from the mixture of bidara leaf extract. As a result of SEM observations, the morphology of bidara leaf extract resembled a lump of oval cabbage measuring around $50 \times 100 \mu \mathrm{m} 2$ with channels similar to small pipes that filled the surface. The unique morphology of the bidara leaf provides an advantage when diffusion reactions between fatty acids and bases. Small pipelines throughout the surface of the bidara leaf extract will provide a large access space for fatty acids to attach to and attract cations from base reagents. In addition, the size of the pipeline is large enough to accommodate a lot of fatty acids and bases. From these observations it can be said that bidara leaf extract plays a major role in the saponification process because it is capable of acting as a saponification reactor. The role of bidara leaves in the saponification process belongs to the soft saponification route or soft saponification of elements other than bases and fatty acids. The element content in biadara leaf extract includes carbon, aluminum, potassium, chlorine and calcium (Table 1). Elements other than carbon and oxygen can act as catalysts that accelerate the saponification process so that compaction of soap is faster. This can be seen from the results of the bidara soap analysis in Table 2 .
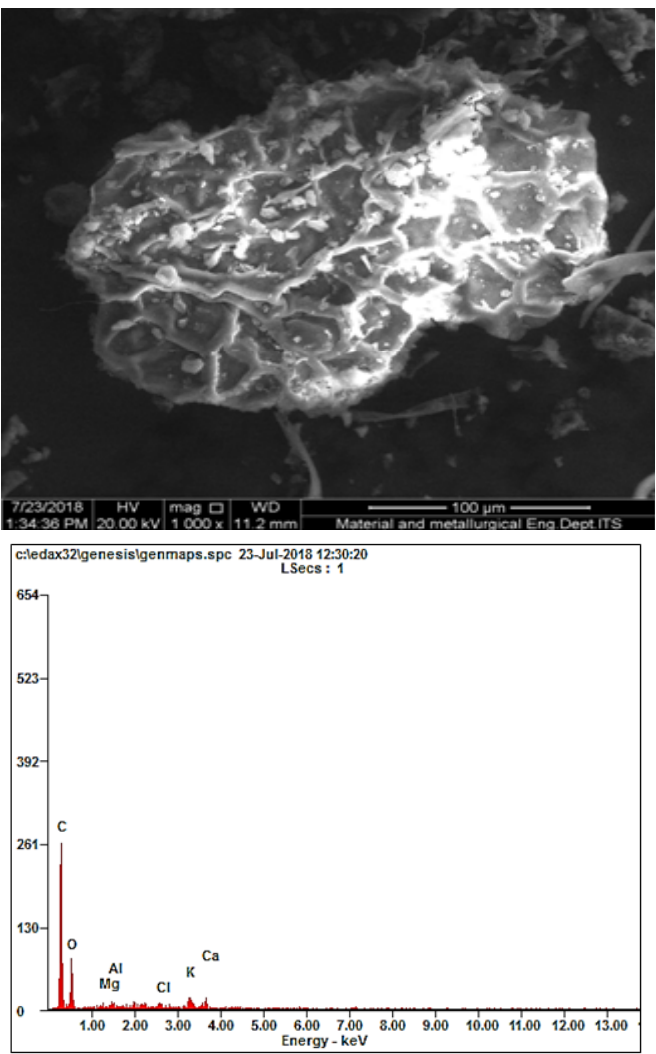

Fig. 2. Results of SEM images (left) and EDX curves (right) on solids of bidara leaf extract

Table 1. elemental Content of bidara leaf extract

\begin{tabular}{cc}
\hline Element & $\% \mathrm{~W}$ \\
\hline $\mathrm{C}$ & 50.54 \\
$\mathrm{O}$ & 0.85 \\
$\mathrm{~A}$ & 0.91 \\
$\mathrm{Cl}$ & 1.42 \\
$\mathrm{~K}$ & 2.48 \\
$\mathrm{Ca}$ & 2.48 \\
\hline
\end{tabular}

Table 2 shows the results of physical analysis carried out on the resulting soap samples. Observations showed that colors from SB-1\%, SB- $2 \%$ and SB-3\% were cream, yellow and orange respectively. The difference in the color of the sample soap is thought to be caused by an increase in fatty acid unsaturation due to the addition of bidara leaf extract. Increased oxidation in bidara soap is thought to cause an increase in color intensity. 
Table 2: Test results for the quality of bidara soap

\begin{tabular}{lcccccr}
\hline Sample & Extract bidara leave (\%) & Colour & Texture & Cleaning power\% & Foam Power \% & pH \\
\hline SB-1\% & 1 & Pale yellow & More Soft & 45 & 51 & 8.7 \\
SB-2\% & 2 & yellow & Soft & 79 & 72 & 9.0 \\
SB-3\% & 3 & Orange & Hard & 72 & 75 & 9.2 \\
\hline
\end{tabular}

Soap texture varies depending on the nature of the concentration of bidara leaf extract which interacts with fatty acids from various oil mixtures. The SB-1\% sample produces softer soap than other samples. This is expected to occur because in the SB-1\% sample the content of the small bidara extract causes the oil dispersion in alkaline substances to be slow. Soap with a low level of oil dispersion will form a molecular structure with molecular content in the form of groups that are easily soluble in water so that the texture of the soap is softer. Table 1 shows that SB-2\% has the highest net power compared to other samples. This is thought to occur because the content of bidara leaves in the SB- $2 \%$ sample is able to interact well with fatty acids in olive oil, palm oil and sunflower oil so that the soap is rich in hydrophilic groups that are able to attract dirt from oil during the sample test. The second estimation is that the bidara leaf extract contains geranyl acetone, methyl hexadecanoate, methyl octadecanoate, farnesil acetone, hexadecanol and ethyl decanoate which have carboxylic, alcohol and ketone functional groups, all of which are able to naturally withdraw oil through electrostatic interactions. This is clarified by the results of the following FTIR spectra.

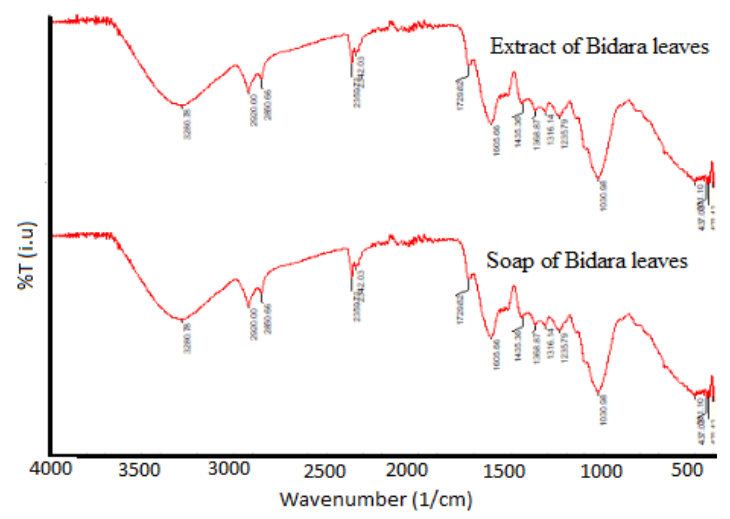

Fig. 3. FTIR of bidara leaf extract and Bidara Leaf Soap

Figure 2 is a FTIR spectra of bidara leaf extract and Bidara Leaf Soap. FTIR spectra show that the $\mathrm{R}-\mathrm{OH}$ group is at wave numbers 1162 $\mathrm{cm}^{-1}$ and $1030 \mathrm{~cm}^{-1}$. The tape on the absorption areas 1292,1347 and 1438 is a description of the
$\mathrm{C}-\mathrm{O}$ and $\mathrm{C}-\mathrm{H}$ strain. $\mathrm{OH}$ and $\mathrm{CH}$ strains are clearly visible in the wave number 3280 and 2992. The peaks in the FTIR leaf spectra are representations of geranyl acetone, methyl hexadecanoate, methyl octadecanoate, farnesyl acetone, hexadecanol and ethyl decanoate which have been reported in previous studies (Patel et al., 1988; Devi et al., 1999). It is also recorded in the FTIR soap spectra of bidara leaves. All primary peaks on the leaves of the bidara were clearly recorded in the bidara leaf soap spectra which meant that after the saponification process, the primary groups of the bidara leaves were still stable and others interacted with fatty acids. The hydrophilicity properties of bidara soap that are well recorded in the clean power test can be logically explained by FTIR spectra which have wide peaks in the -O-H strain section. In other words, the wider and taper the peaks such as the $-\mathrm{O}-\mathrm{H}$ and $\mathrm{R}-\mathrm{OH}$ strain, the stronger the hydrophilicity properties of the sample. The hydrophilicity properties are also related to the acidity conditions that will be explained by the $\mathrm{pH}$ test.

In the acidity test, the SB-1\% sample had the lowest $\mathrm{pH}$ because it was estimated in the alkali acid base group leaf extract which added the $\mathrm{pH}$ value of the soap. The second estimate is that the more bidara leaves added during the saponophication process, the more effective the saponification process will be because the bidara leaves become a catalyst that pushes the cation in the alkaline solution to diffuse more on the surface of the fatty acid so that the resulting soap has a high $\mathrm{pH}$. In the manufacture of soap in general, a $\mathrm{pH}$ that is too high is not very preferred because it causes irritation to the skin so that a good standard of soap has a $\mathrm{pH}$ below 9.8. In general, all bidara leaf soap samples meet the requirements for use as soap because all test results meet the standards. The addition of bidara leaf extract produces soap with better clean power and a comfortable texture in the skin so that the bidara leaves can be a potential natural ingredient in the development of quality soap in the future. 


\section{Kesimpulan}

Bidara leaf soap preparation was successfully carried out with various concentrations of bidara leaf extract. The results of the test and soap characterization showed that the bidara leaves had carbon content and hydrophilic groups capable of increasing the saponification reaction rate. In addition, the presence of bidara leaves will produce soap with a bright color, soft texture, high foam power, good clean power and a $\mathrm{pH}$ that suits the skin. From the overall test results it can be concluded that bidara leaf soap can be an alternative to potential body cleaning agents.

\section{ACKNOWLEDGEMENT}

Financial support from the Sebelas Maret University from PNPB Program 2019 in Scheme Research Group Capacity Building Research (Penelitian Peningkatan Kapasitas Riset Group (PPKGR), in collaboration with Boarding School of Darul Fath, Salakan Pengging Boyolali Indonesia, is gratefully acknowledged

\section{REFERENCES}

1. Pohl N. L. B; Streff J. M. Brokman S., Evaluating Sustainability: Soap versus Biodiesel Production from Plant Oils., J. Chem. Educ., 2012, 89(8) 1053-1056.

2. Phanstiel O., Dueno E., Wang Q.X., Synthesis of Exotic Soaps in the Chemistry Laboratory. J. Chem. Educ., 1998, 75(5) 612-614.

3. Mabrouk S.T., Making Useable Quality Opaque or Transparent Soap J. Chem. Educ., 2005, 82(10):1534-1537.

4. KatzD.A.The Science of Soaps and Detergents., Chymer Accessed at \http:// www. chymer. com/soap $\%$ and 20 detergent. pdf 12/1/2009., 2000.

5. Robertson D.L, Saponification and Making Soap. Experiment 8- Chemistry102 Experiments. Miracosta Index. Available at http://www.miracosta.cc.ca.us/home/dlr/102 exp8. htm Accessed 22/3/2009., 2009.

6. Sani., N.A and HassanL.G.,Preparation and analysis of the physical and chemical Properties of soap from lageneria siceraria (Bottle ground)seeds oil., Namoda Techscope Journal., 2007., 7(1), 23-32.

7. Patel, B.H; Upadhyay V.R Mauralidharann., C.M.,Effect of various insecticide honey bee and Apis florea Fabiricius (Zizypus
Mauritania)., Current sciences Journal., 1988, 1199-1202.

8. Devi., K.S., Atluri. J.B., Reddi., C.S., Polination ecology of Zizypus Mauritania., Plant sciences., 1999., 99(3), 220-22.

9. Ganesh N, S., \& Amit, G. Ziziphus mauritiana lam-an overview. Indo AmericanJournal Of Pharmaceutical Research., 2013, 3(6), 4560-4566.

10. Kim, J. H., Ha, S. Y., Nam, S. Y., Rhim, J. W., Baek, K. H., \& Lee, Y. M. Selective permeation of $\mathrm{CO}_{2}$ through pore-filled polyacrylonitrile membrane with poly(ethylene glycol). Journal of Membrane Science., 2001, 186(1), 97-107. https://doi.org/10.1016/S0376-7388 (00)00670-0.

11. Sutheimer, S., Caster, J. M., \& Smith, S. H. Green Soap: An Extraction and Saponification of Avocado Oil. Journal of Chemical Education., 2015, 92(10), 1763-1765. https:// doi.org/10.1021/acs.jchemed.5b00188.

12. Warra, A. A., Hassan, L. G., Gunu, S. Y., \& Jega, S. A. ColdProcess Synthesis and Properties of Soaps Prepared from Different Triacylglycerol Sources. Nigerian Journal of Basic and Applied Science., 2010, 18(2), 315321. https://doi.org/10.4314/njbas. v18i2.64350. 